\title{
Nominal Group Technique: a Brainstorming Tool for Identifying Learning Activities Using Musical Instruments to Enhance Creativity and Imagination of Young Children.
}

\author{
Abdul Talib Hashim* \\ Azli Ariffin \\ Abdul Rahim Razalli \\ Abd Aziz Shukor \\ Mohd NizamNasrifan \\ Abdul Kadir Ariffin \\ Abu Bakar Yusof \\ Noor-Amy Afiza Yusof \\ National Child Development Research Center, \\ Sultan Idris Education University (UPSI), Malaysia.
}

\begin{abstract}
The purpose of this study is to identify consensus by experts on appropriate activities to enhance the development of preschool children's imagination through the use of musical instruments. In order to obtain an in-depth understanding of teachers' conceptions on imagination in creativity development and their beliefs about the best way to promote imagination in the classroom, the nominal group technique (NGT) was used to structure each focus group meeting. Finding shows a list of activities that have been sorted according to ranking as determined by the experts. All the experts also believe that the list of activities can boost the child's imagination because such activities have the characteristics that suit well with children.
\end{abstract}

Keywords: Nominal Group Technique, creativity, imagination, musical instrument, pre-school curriculum

\section{Introduction}

Creativity building among children concerns on two elements that need to be addressed, namely imagination and expression (Vygotsky, 1967; Kim, Kaufman \& Sriraman, 2013). According to Susan (2010), imagination of a child at an early stage is at a very high level. The child must be given ample opportunity and enough space for their imagination to take place in order for them to think creatively. According to Egan (1999), his study emphasized that imagination is a need to ensure that we think and be creative constantly in our modern society. Meantime, art allow us to keep on imagine (Gadsden, 2008). He also affirms that art:

... allow individuals to put their place in the skin of another; to experience reality and culture of others; to sit in another space; to transport themselves across time, space, era in history, and context; and to see the world from different point.(Gadsden, 2008)

Imaginative activities are involved in the creative process because creative ideas are generated through imaginative ability. The ability to imagine is an essential prerequisite to publish and translate creative ideas (Azhar, 2004; Callahan \& Miller, 2005; Beghetto, 2009). The ability to imagine are within every individual and it can be performed any time and in any situation regardless of age and background level. Nevertheless, to be a creative person, the ability to imagine is one of the 
most important factors of being a human. Imagination can be triggered using words to describe or illustrate certain abstract, view the conflict events or occurrences, reverse a hypothetical events, and using alternative thinking to something that has been considered (Schirrmacher, 2002; Reis \& Renzulli, 2009; Aubrey, Ghent \& Kanira (2012). Critical thinking can permeate all aspects and beyond these aspects critical thinking is the real imagination activator. Imagination is usually associated with the allegation that fantasy practices as something that do not exist. But imagination in actual is the basis for any creative activity and it is an important component in every aspect of human life (Kim, Kaufman \& Sriraman (2013).

\section{Developing children creativity and imagination}

Built imaginations are often based on material obtained from reality through one's environment and experience. Moreover this factor is very important that influence one's imaginative ability. In addition, imagination also plays an important role on human action and development (Pfeiffer (2012). Every human experience is translated through imagination because it is through imagination that human can conceive something that cannot be seen, describing information obtained through stories of others and describing something that are experienced by other people. The relationship between imagination and experience are closely intertwined and constantly influence each other (Pfeiffer \& Thompson, 2013). Apart from experience, imagination can also be influenced by one's emotions. Each feelings and emotions require different forms of imagination. This is because each feelings and emotions that are seen and experienced will produce different imagination (Ribot, 1906; Vygotsky, 1967). In one particular situation, emotions may affect imagination; nevertheless imagination may also affect emotions. Schirrmacher (2002) explains that creativity is dependent on one's environment. Each creator includes those brilliant inventors who are product of their time and environment.

Studies show that a decrease in the level of a child's imagination is caused by environment and culture of the child rather than caused by natural process (Torrance, 1974; Runco, Millar, Acar, \& Cramond, 2010; Pfeiffer, 2012; Kim, Kaufman \& Sriraman, 2013). Children should be exposed to different forms of experience so that they have the opportunity to play with fantasy in order to encourage them to imagine.

National Pre-School Standard Curriculum (KSPK) which was implemented in 2011, explains that there are six learning cores which are similar to the cores focused in primary education, namely: Communication; Spirituality, Attitudes and Values; Humanities; Science and Technology; Aesthetic and Physical Development and Personal Skills Development. Creativity Domain Standard (SDK) is one of the domains in the curriculum that is made up of two components, namely fostering creative thinking and creative attitude and personality (Ministry of Education, 2009). Each child is considered as having the creativity potential naturally. However, appropriate nurturing, guidance, encouragement and environment are essential in producing creative and innovative individuals (Ministry of Education, 2009). It is intended to provide opportunities and space for children to think in a creative and innovative manner and to generate individuals with the following characteristics:

1. keep asking and looking for answers,

2. making associations and observing correlation,

3. anticipating on future events and happenings,

4. making speculation on possibilities, and

5. exploring ideas, actions and results.

According to KSPK, creativity and innovation can be further developed through two main approaches. The first is implementation on all cores through teaching and learning activities and second is implementation through music and visual art education (Ministry of Education, 2009). Through this approach, development of children will have the opportunity to express their ideas creatively and engage in musical activities healthily. Teachers who teach preschoolers were often seen as individuals who are able to enhance children's creativity. Nevertheless it was found that most teachers in preschool level are incapable to help in nurturing the values of individuality, creativity, imagination and aesthetic appreciation (Wong and Lau, 2001).

Music can be seen as one of the tools that contribute to the children holistic development which includes the intellectual, emotional, physical, social and aesthetic developments (Steele, Bass, and Crook, 1999; McKelvie \& Low, 2002; Norton, Winner, Cronin, Lee, and Schlaug, 2005). This is because musical activity is an integral part of their daily activities such as singing, moving, dancing, and playing musical instruments and the sounds that they produced on their own (Anvari, Trainor, 
Woodside \& Levy, 2002; Gordon, 2003; Legg, 2009; Hash, 2010). Despite the importance of creativity and the role of music in the development of children education has long been recognized in Malaysian preschool education, but their appreciation, understanding and implementation are often put into question (Ministry of Education, 2009). In reality the present preschool education curriculum are more focused on formal education that emphasizes academic achievement of preschoolers (Rohaty, 1984, Aliza Ali, Zahara Aziz \& Rohaty Majzub, 2011). The emphasis contradicts with the specialists' view on child development (Vygotsky, 1967; Fortson \& Reiff, 1995; McAlister \& Peterson, 2012) who often emphasized that comprehensive children development through creativity and aesthetic construction should be raised in the process of teaching and learning in preschool education.

Thus, in the process of creating an innovative society that is viable in a challenging environment which further lead to wellbeing of society and country, such vigorous effort should be carried out in a prudent and systematic manner as well as going through appropriate process (Wellman, Cross \& Watson, 2011; Dore \& Lillard, 2015). The endeavor aims to generate individuals with innovative ability whereby characters of a creative innovator must exist within individuals and in order to nurture creative individuals; there should be ability to imagine.

This study is mainly to identify consensus by experts on appropriate activities to enhance the development of preschool children's imagination through the use of musical instruments. The main objectives of this study are to explore and understand related activities to improve preschool children's imagination through musical instruments.

\section{Research Design}

This exploratory study uses qualitative method to provide further understanding on the area being investigated. The use of qualitative method is appropriate for this study because it is an attempt to understand the phenomenon of interest from the participant's perspective rather than the researcher's (Creswell, 2014). In order to obtain an in-depth understanding of teachers' conceptions on imagination in creativity development and their beliefs about the best way to promote imagination in the classroom, the nominal group technique (NGT) was used to structure each focus group meeting (Delbecq, Van de Ven, \& Gustafson, 1975). NGT is a strategic and effective means of harnessing social facilitation processes so that group productivity on a given task is optimized (Forsyth, 1990). Prior to an NGT meeting, it is important to understand the informational needs to be addressed along with this procedure. Once the objectives are well understood, focus should be given on structuring questions posed to the group because wordings and grammatical structure of the questions will affect the levels of abstraction, breadth, and depth of the elicited responses. According to Delbecq et al. (1975), broadly stated or unfocused NGT questions are likely to elicit a variety of responses from respondents who have had varied experiences. Questions should be framed so that participants can generate information that sufficiently conveys their understanding of the issue under study.

\subsection{Sampling}

Subjects of this study consisted of nine preschool teachers who were purposively selected from nine government schools. As Denzin and Lincoln (1994) put it, many qualitative researchers employ purposive rather than random, sampling methods. Within the context of this study, the teachers were purposely selected because they might show differences in ideas, beliefs and practices due to their different characters in personality and physical settings.

\subsection{Data Collection Methods}

Nominal group technique (NGT) is a structured variation of a small-group discussion to reach consensus (Frankel, 1987). NGT gathers information by asking individuals to respond to questions posed by a moderator, and later ask the participants to prioritize ideas or suggestions of all the group members (Fink, Kosecoff, Chassin, \& Brook, 1984). The process prevents the discussion from being dominated by a single member, encourages all group members to participate, and produces result in a set of prioritized solutions or recommendations that represent the group's preferences.

NGT is a good method to gain group consensus, for example, when various people (program staff, stakeholders, community residents, etc.) are involved in constructing a logic model and the list of outputs for a specific component is too lengthy therefore the list has to be prioritized (Frankel, 1987; Gallagher, Hares, Spencer, Bradshaw \& Webb, 1993). In this case, the questions to be considered are: "Which of our outputs listed are the most important for easier goal achievement and 
easier measurement? Which of our outputs are less important that make us difficult to achieve our goal and make it more difficult for us to measure?"

\section{The Four-Step Process to Conduct NGT}

\section{Generating Ideas:}

The moderator presents questions or problem to the group in written form and reads the question to the group. The moderator directs everyone to write ideas in brief phrases or statements and asks them to work silently and independently. Each person silently generates ideas and writes them down.

\section{Recording Ideas:}

Group members engage in a round-robin feedback session to concisely record each idea (without debate at this point). The moderator writes an idea from a group member on a flip chart that is visible to the entire group, and proceeds to ask for another idea from the next group member, and the process continues. Repeat of ideas is unnecessary; however, if the group members feel that a particular idea provides different emphasis or variation, they are free to include the idea. The process is carried out until ideas of all the group members have been documented.

\section{Discussing Ideas:}

Each recorded idea is later discussed to determine clarity and importance. For each idea, the moderator asks, "Are there any questions or comments that group members would like to make about the item?" This step provides an opportunity for members to express their understanding of the logic and the relative importance of the item. The creator of the idea need not feel obliged to clarify or explain the item; any member of the group can play that role.

\section{Voting on Ideas:}

Individuals vote privately to prioritize the ideas. The votes are tallied to identify the ideas that are rated highest by the group as a whole. The moderator establishes what criteria are used to prioritize the ideas.

\section{Findings}

Findings were obtained from 11 experts involved throughout the NGT process. This process uses one set of seven Likert scale questionnaire that consists of a list of 16 activities sorted from previous literature review and need analysis. Table 1 show the list of sorted activities which are as follows.

Table 1: Proposed Activity List

\begin{tabular}{|l|}
\hline Proposed Activity List \\
\hline Playing the musical instruments to children. \\
\hline Describing the musical instrument being played \\
\hline Having a question and answer session (Q\&A) with the children about musical instruments \\
\hline Showing pictures related to musical instruments \\
\hline Showing materials related to musical instruments \\
\hline Making motion related to sound of musical instruments \\
\hline Talking about existing experience related to musical instruments \\
\hline Making movement on the existing experience related to musical instruments \\
\hline Singing while playing a percussion \\
\hline
\end{tabular}


Playing a role based on musical instruments

Playing percussion instruments independently

Exploring environment that has to do with musical instruments

Creating a scrapbook on musical instruments

Forming objects using dough / Lego/ block / sand / puzzle based on the sound of musical instruments

Creating visual art activities (origami / collage / painting / shaping / coloring / drawing / painting / weaving / diorama etc.) based on musical instruments

Creating a play/pantomime based on musical instruments

The experts need to choose their agreement level on all of the activities listed. Next, the total of agreement level by the experts for each activity is calculated to determine the activity ranking that need to be carried out first. The total approval is as shown in Table 2.

Table 2: Expert's Voting and Ranking

\begin{tabular}{|c|c|c|}
\hline Proposed Activity List & Total & Ranking \\
\hline Playing the musical instruments to children. & 74 & 6 \\
\hline Describing the musical instrument being played & 72 & 14 \\
\hline Having a question and answer session (Q\&A) with the children about musical instruments & 76 & 1 \\
\hline Showing pictures related to musical instruments & 74 & 7 \\
\hline Showing materials related to musical instruments & 75 & 2 \\
\hline Making motion related to sound of musical instruments & 75 & 3 \\
\hline Talking about existing experience related to musical instruments & 74 & 8 \\
\hline Making movement on the existing experience related to musical instruments & 74 & 9 \\
\hline Singing while playing a percussion & 74 & 10 \\
\hline Playing a role based on musical instruments & 75 & 4 \\
\hline Playing percussion instruments independently & 75 & 5 \\
\hline Exploring environment that has to do with musical instruments & 72 & 15 \\
\hline Creating a scrapbook on musical instruments & 71 & 16 \\
\hline $\begin{array}{l}\text { Forming objects using dough / Lego/ block / sand / puzzle based on the sound of musical } \\
\text { instruments }\end{array}$ & 74 & 11 \\
\hline $\begin{array}{l}\text { Creating visual art activities (origami / collage / painting / shaping / coloring / drawing / painting } \\
\text { / weaving / diorama etc.) based on musical instruments }\end{array}$ & 73 & 12 \\
\hline Creating a play/pantomime based on musical instruments & 73 & 13 \\
\hline
\end{tabular}

Table 3 shows a list of activities that have been sorted according to ranking as determined by the experts. 
Table 3: List of Activities After the Nominal Group Technique (Ngt) Process

List of Activities After the Ngt Process

Having a question and answer session $(Q \& A)$ with the children about musical instruments

Showing materials related to musical instruments

Making motion related to sound of musical instruments

Playing a role based on musical instruments

Playing percussion instruments independently

Playing the musical instruments to children.

Showing pictures related to musical instruments

Talking about existing experience related to musical instruments

Making movement on the existing experience related to musical instruments

Singing while playing a percussion

Forming objects using dough / Lego/ block / sand / puzzle based on the sound of musical instruments

Creating visual art activities (origami / collage / painting / shaping / coloring / drawing / painting / weaving / diorama etc.) based on musical instruments

Creating a play/pantomine based on musical instruments

Describing the musical instrument being played

Exploring environment that has to do with musical instruments

Creating a scrapbook on musical instruments

\section{Conclusions}

The nominal group technique (NGT) is a group discussion technique to reach consensus for problem solving. In this study we believe that teachers are in position to either enhance or inhibit development of children's imagination, thus they should make an effort to promote imagination in the classroom. Group discussion on our main ideas has been implemented in a structured, systematic and creative manner. For evidence through NGT, we have managed to encourage each group members who are actively involved to think, produce ideas or opinions without influence of others. They have also managed to examine every idea, formulate and make priority of objectives. The idea that gets the most votes will be taken as group decision. In some circumstances, if the idea was considered unsatisfactory, we will repeat the selection process until majority of the group members are satisfied to achieve the best ideas and to produce the best quality. It is our hope that the activities proposed in this paper could realize our aim to promote children's creativity through the power of imagination.

After the completion of the process described above, we thought that NGT is appropriate in order to get the best idea to undertake a study or solve issues on education. This is because the NGT has been able to reduce the dominance of opinion by experts who have a higher status and aggressive. We found that all the members of the panel have the same opportunities. The group is also aware of the objectives to be formulated, as well as making evaluation or critique of the topic being discussed. In addition, we were also able to develop a democratic and creative atmosphere, and reducing inefficiencies during the discussion. 
However, there were also drawbacks of the NGT in this study. We are aware that the selected panel have a lot of experience and well versed in the discussion on teaching and learning issues. Therefore it is also quite difficult for them to reach consensus on an alternative at a final decision. This is because the whole process is more time consuming, lengthy and long. Furthermore, each of the 11 selected panels has unconsciously presented their different interests during the discussion. There was bias in the opinions and proposals that they submitted, but was reduced after the panel voting. The most important of all, the decisions that were mutually agreed (see Table 2 and 3 ) have proved consensus among them in working together to implement and achieve the best results to enhance creativity and imagination of young children.

\section{References}

[1] Aliza Ali, Zahara Aziz \& Rohaty Majzub. (2011). Teaching and learning through play. World Applied Sciences Journal, 14, 15-20.

[2] Anvari, S., Trainor, L., Woodside, J., \& Levy, B., (2002). Relations among musical skills, phonological processing and early reading ability in preschool children, Journal of Experimental Child Psychology, 83(2), 111-130. doi:10.1016/S0022-0965(02)001248.

[3] Aubrey, C. , Ghent, K. \& Kanira, E. (2012) Enhancing thinking skills in early childhood, International Journal of Early Years Education, 20:4, 332-348. doi:10.1080/09669760.2012.743102

[4] Azhar Abd. Hamid (2004). Kreativiti: Konsep Teori \& Praktis: UTM. Johor D.T.

[5] Creswell, J. W. (2014). Research design: Qualitative, quantitative, and mixed method approaches, (4th ed.), Thousand Oaks, CA: Sage.

[6] Delbecq, A. L., Van de Ven, A. H., \& Gustafson, D. H. (1975). Group techniques for program planning: A guide to nominal group and delphi processes, Glenview, IL:Scott, Foresman.

[7] Dore, R. A \& Lillard, A.S (2015). Theory of Mind and Children's Engagement in Fantasy Worlds, Imagination, Cognition and Personality: Consciousness in Theory, Research, and Clinical Practice, 34 (3), 230-242. doi: 10.1177/0276236614568631

[8] Egan, K. (1999). Children's minds, talking rabbits and clockwork oranges: Essays on education. New York: Teachers College Press.

[9] Frankel, S. (1987): Methodological observations on applied behavioral science, Journal of Applied Behavioral Science, 23: 543-551.

[10] Fink, A., Kosecoff, J., Chassin, M. \& Brook, R. H. (1984): Consensus methods: characteristics and guidelines for use, American Journal of Public Health, 74: 979-83.

[11] Forsyth, D. R. (1990).Group dynamics (2nd ed.). Belmont, CA: Brooks/Cole.

[12] Fortson, L. R., \& Reiff, J. C. (1995).Early childhood curriculum: Open structures for integrative learning. Boston, MA: Allyn and Bacon.

[13] Gadsden, V.L. (2008). The arts and education: Knowledge generation, pedagogy, and the discourse of learning. Review of Research in Education, 32, 29-61.

[14] Gallagher, M., Hares, T., Spencer, J., Bradshaw, C. \& Webb, I. (1993). The nominal group technique: A research tool for general practice? Family Practice, 10: 76-81.

[15] Gordon, E. (2003). A music learning theory for newborn and young children, Chicago: GIA.

[16] Hash, P. M. (2010). Preservice classroom teachers' attitudes toward music in the elementary curriculum, Journal of Music Teacher Education, 19, 6-24. doi: 10.1177/1057083709345632 
[17] Legg, R. (2009). Using music to accelerate language learning: An experimental study, Research in Education, 82(1), 1-12. doi: 10.7227/ RIE.82.1

[18] McAlister, A. R., \& Peterson, C. C. (2012). Siblings, theory of mind, and executive functioning in children aged 3-6 years: New longitudinal evidence, Child Development, 84(4), 1442-1458. doi:10.1111/cdev.12043

[19] McKelvie, P. \& Low, J. (2002). Listening to Mozart does not improve children's spatial ability: Final curtains for the Mozart effect, British Journal of Development Psychology, 20, 241- 258

[20] Ministry of Education Malaysia (2009).Kurikulum Standard Prasekolah Kebangsaan. Kuala Lumpur: Dewan Bahasa dan Pustaka.

[21] Norton, A., Winner, E., Cronin, K., Lee, D., \& Schlaug, G. (2005). Are there pre-existing neural, cognitive, or motoric markers for musical ability?. Brain and Cognition, 59(2), 124-134. doi:10.1016/j.bandc.2005.05.009.

[22] Ribot, T. (1906). Essay on the creative imagination. London: Kegan Paul, Trench, Truber.

[23] Rohaty Mohd Majzub (1984).Pendidikan prasekolah: Cabaran kualiti. Shah Alam: Penerbit Universiti Kebangsaan Malaysia.

[24] Schirrmacher, R. (2002). Art and creative development for young children. Albany, New York: Delmar Thomson Learning.

[25] Steele, K.M., Bass, K.E., Crook, M.D., (1999). The mystery of the Mozart effect: Failure to replicate. American Psychological Society, Vol. 10, No. 4.

[26] Susan, W. (2010).Understanding Creativity in Early Childhood.London: Sage.

[27] Torrance, E. P. (1974). Torrance Tests of Creative Thinking: Norms-technical manual. Bensenville, IL: Scholastic Testing Service. (Originally published by Personnel Press, 1996).

[28] Vygotsky, L. S. (1967). Play and its role in the mental development of the child, Soviet Psychology, 5, 6-18.

[29] Wellman, H. M., Cross, D., \& Watson, J. (2011). Meta-analysis of theory-of-mind development: The truth about false belief, Child Development, 72(3), 655-684. doi:10.1111/1467-8624.00304

[30] Wong, S. S., \& Lau, W. C. (2001b, May).An innovative movement and music approach for preschool curriculum in Hong Kong. Paper presented at the International Conference Rejuvenation Schools through Partnership, Chinese University, Hong Kong.

\section{Funding}

This research is supported by the National Child Development Research Center (NCDRC) grant [grant number 2015-0084107-04]. 